\title{
Health issues in the Hajj pilgrimage: a literature review
}

Mae Aldossari, ${ }^{1}$ Abdullah Aljoudi, ${ }^{2}$ David Celentano ${ }^{3}$

${ }^{1}$ Department of Health Policy and Management, Johns Hopkins Bloomberg School of Public Health, Johns Hopkins University, Baltimore, Maryland, United States of America (Correspondence to: M.R. Aldossari: maldoss $@$ @jhu.edu). ${ }^{2}$ Department of Global Health and Social Medicine, Harvard Medical School, Harvard University, Boston, Massachussetts, United States of America. ${ }^{3}$ Department of Epidemiology, Johns Hopkins Bloomberg School of Public Health, Johns Hopkins University, Baltimore, Maryland, United States of America.

\begin{abstract}
The Hajj pilgrimage to Mecca, Saudi Arabia, is one of the largest annual mass gatherings in the world, and has a strong impact on international public health. This paper presents an overview from a systematic search of the published literature on health risks and services in the Hajj for 2005-2014, with the aim of providing health policy recommendations to prevent health risks. Of the 335 studies initially identified, 60 met the inclusion criteria for the review. Studies identified were diverse in methodology and focus. The results were classified into 3 main categories: communicable diseases, noncommunicable diseases and health services. Although, improvement was observed throughout the years, there are always new public health challenges in each Hajj season. There is a need to improve health management of the Hajj, particularly by strengthening international collaboration.

Keywords: communicable diseases, Hajj, health services, noncommunicable diseases, public health.

Citation: Aldossari M; Aljoudi A; Celentano D. Health issues in the Hajj pilgrimage: a literature review. East Mediterr Health J. 2019;25(10):744-753.

https://doi.org/10.26719/2019.25.10.744

Received: 09/08/17; accepted: 08/03/18

Copyright (C) World Health Organization (WHO) 2019. Some rights reserved. This work is available under the CC BY-NC-SA 3.0 IGO license https:// creativecommons.org/licenses/by-nc-sa/3.o/igo
\end{abstract}

\section{Introduction}

The Hajj pilgrimage is one of the greatest mass gatherings in the world, and presents unique public health challenges. Millions of Muslims from around the world gather annually to perform the Hajj pilgrimage in Mecca, in Saudi Arabia (Figure 1). Hajj is one of the 5 pillars of Islam; therefore, it is mandatory for all Muslims, who are physically and financially capable, to make the journey to Mecca once in a lifetime.

The season of the Hajj varies, due to its adherence to the Islamic lunar calendar. The Hajj takes place in month 12 of the lunar calendar, for 5 days, from days 8 to 12 . In the last decade, the pilgrimage has taken place in fall and winter, having occurred in January 2005, and advancing to October 2013. These months have been associated with winter diseases. As the lunar calendar advances over the next decade, the Hajj will take place in summer months, and different diseases will be dominant.

Pilgrims performing the Hajj are predisposed to diverse and significant health risks, due to the limited time and confined geographical area of the event, and the large numbers of people, with population densities among the millions of participants, reaching 7 persons $/ \mathrm{m}^{2}(1)$.

The activities of the Hajj are now summarized, to provide context for the consideration of the attendant health aspects. Around 2 million Muslims arrive in Mecca. On day 1, the pilgrimage starts at the Grand Mosque with the ritual of Tawaf, circling 7 times around the central building (Kaaba). It then continues with the ritual of Saee, running 7 times between 2 small hills (Safa and Marwah) near the Grand Mosque and proceeding to Mina where they spend the whole night. On day
2, the pilgrims go to the plain of Arafat, about 8 miles east of Mecca, to perform what is called the Standing at Arafat; an afternoon of prayer and contemplation that is considered the highlight of the Hajj. After sunset, the pilgrims travel back towards Mecca, stopping to spend the night in Muzdalifa. On day 3, the pilgrims perform the ritual of Ramy Aljamrat, which involves throwing stones at a pillar in Mina, a neighbourhood in Mecca, and creates the densest crowds during the Hajj. Following that, pilgrims sacrifice an animal (a camel, cow or sheep). On days 4 and 5, pilgrims stay in Mina. On day 5, they move from Mina to Mecca, perform the final farewell ritual of Tawaf and Saee, and then leave Mecca.

The Saudi government provides free healthcare services for all pilgrims. In 1437 (Islamic calendar) (2016 Gregorian calendar), the healthcare system consisted of 27 hospitals with a total capacity of 5038 beds, and 154 health centres (2). The healthcare system, which is operated by 26421 domestic employees in addition to international visiting healthcare practitioners, provides curative and preventive services. The preventive services include infectious disease surveillance, outbreak investigations, mass vaccinations, mass administration of prophylactic medications, environmental health services, and health education. The health education activities include awareness campaigns, distribution of pamphlets to arriving pilgrims, and establishing toll-free telephone lines operated by trained healthcare providers. The data reported from different departments in hospitals and primary care centres, in addition to the surveillance data, feed the electronic web-based healthcare surveillance network at the Command and Control Center in Mecca, and are published in the annual statistical book of the Saudi Ministry of Health $(2,3)$. 


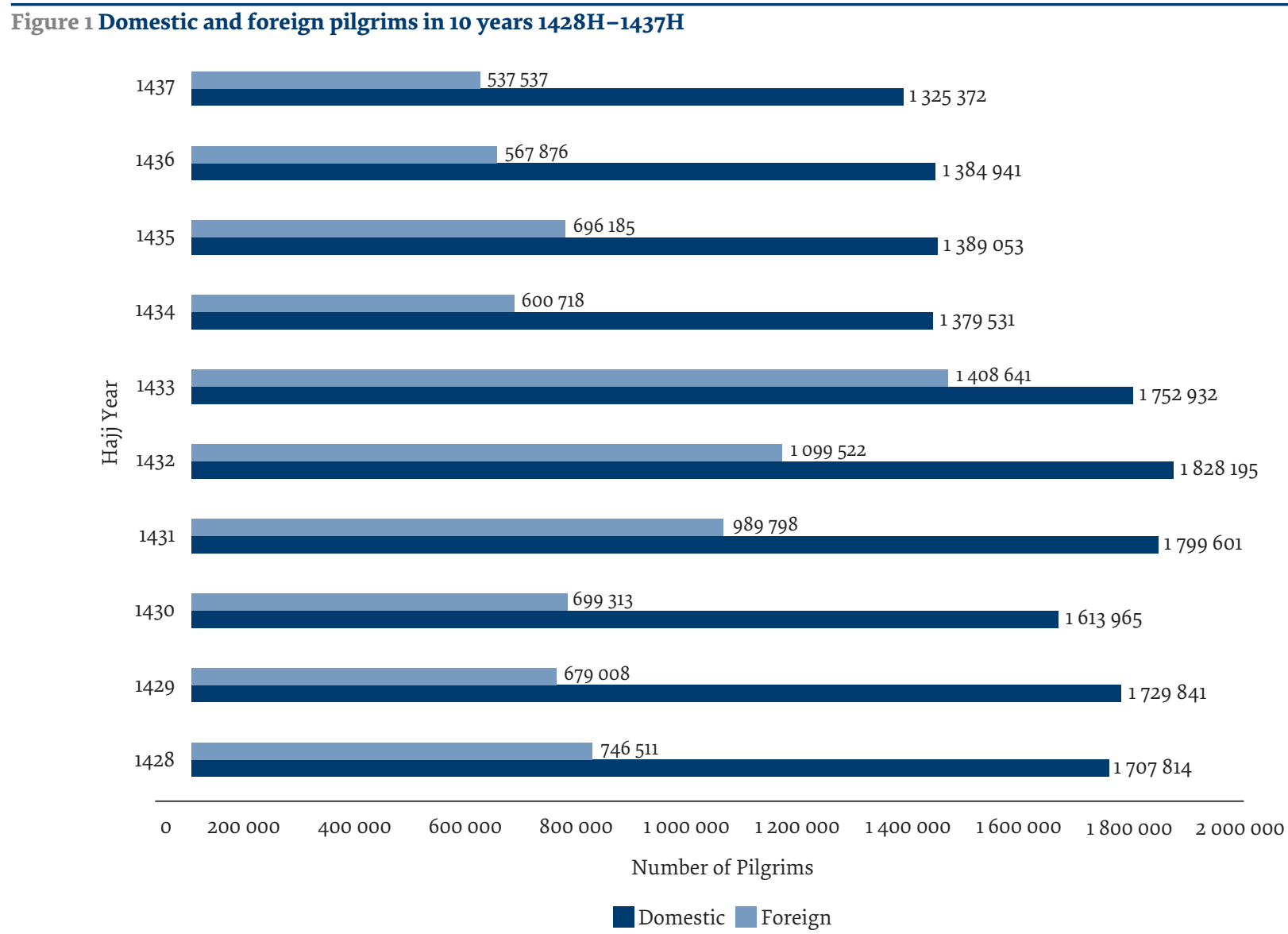

In 2006, The Lancet published a review entitled: "Health risks at the Hajj" (4). Since then, some trends in health risks have changed; for example, several emerging infectious diseases have arisen, such as influenza A H1N1, severe acute respiratory syndrome and Middle East respiratory syndrome (MERS) (3), and new policies to control health risks in the Hajj have been implemented, such as administering polio vaccine to pilgrims on arrival in Saudi Arabia, and reducing Hajj quotas for foreign and domestic pilgrims in 2013 (3). The present study presents an updated comprehensive review about the health issues in the Hajj, with the aim of providing policy recommendations to prevent these risks.

\section{Methods}

\section{Search strategy}

A search was conducted for English-language publications in PubMed, Embase and CINAHL for 2005-2014 using the keywords: "Hajj", "Haj", "Hadj", "pilgrimage" and "pilgrims". We also searched the reference lists of all the identified publications for additional sources. These searches yielded 335 publications (Figure 2).

\section{Eligibility of studies}

We included studies that addressed health aspects of the Hajj. All articles described as original, research, or leading articles were included. No restriction on the type of study design was made. No attempt was made to score methodologies due to the heterogeneous nature of the included studies. In addition to excluding the studies with a sample size $<100$, reviews, editorials, comments, correspondence and case reports were excluded. Figure 2 shows the flow chart of the search inclusion and exclusion process.

\section{Analysis}

Each of the eligible publications was carefully read, and 9 key data elements were extracted: authors, objectives, year of the Hajj, study design, population, data collection, sampling methods, sample size, and results (Table 1 online). The findings were then organized into coherent themes using a narrative review approach, which identified common elements in the studies. Due to the heterogeneity of the studies included in this narrative review, a qualitative method to consolidate the data was used and not quantitative (statistical) methods. The information about certain diseases was gathered from different publications and then reported in one place.

\section{Results}

The 60 papers fulfilling the eligibility criteria represented studies that were variable in their scope and methodology. The results were classified into 3 main categories: communicable diseases, noncommunicable diseases, and Hajj health services. 


\section{Communicable diseases}

\section{Meningococcal disease}

Crowded conditions are a risk factor for the carriage and transmission of Neisseria meningitides, and the Hajj has been associated with outbreaks of invasive meningococcal disease. During the 2000 and 2001 Hajj pilgrimages, Saudi Arabia experienced 2 large outbreaks of invasive meningococcal disease that led to global spread of N. meningitides serogroup W-135 (5). Studies from Oman, Sudan, United States of America, Brazil and Turkey showed that the risk of becoming infected by the Hajj clone N. meningitides W135 spread beyond the borders of Saudi Arabia (6-10). Meningococcal disease outbreaks are likely during the Hajj, and they have high fatality rates and associated medical costs; therefore, preventive measures are needed to control its transmission. These include prescriptions of a single dose of $500 \mathrm{mg}$ ciprofloxacin to all pilgrims before arrival back in their home country (11).

\section{Respiratory tract infection}

Many studies showed that respiratory diseases are the most common cause of outpatient department visits during the Hajj, accounting for $41-60.8 \%$ of visits (12-15). In the Ear, Nose and Throat (ENT) clinic alone, upper respiratory tract infections (URTIs), including pharyngitis, viral URTI, and tonsillitis, represented $85.2 \%$ of the total diagnoses (16). In a study of 250 international pilgrims, $25.6 \%$ of them developed URTI (13). Another study among domestic pilgrims showed that $39.8 \%$ of them developed URTI (17). In a French study, $16.6 \%$ of French pilgrims experienced fever during their stay in Saudi Arabia and $60.6 \%$ had a cough (18). In a Malaysian study of 394 pilgrims, 95.2\% had respiratory symptoms (19).

Comorbidity is one of the risk factors for development of URTI. In pilgrims who suffered from comorbidity, there was a significant association with longer duration of cough $(P=0.041)$, longer duration of sore throat $(P=0.048)$, and severe influenza-like illness requiring admission to hospital for further treatment $(P=0.016)(20)$.

Several studies evaluated the type of pathogens causing respiratory infections among pilgrims (21-24). One study confirmed that acute respiratory infections were caused by influenza virus (IV) or respiratory syncytial virus (RSV) (21). Influenza A virus (IAV) $\mathrm{H}_{3}$ accounted for $54 \%$ of the virus-positive samples, followed by RSV (24\%), influenza B virus (IBV) (19\%) and IAV H1 (3\%). Alborzi et al. (23) showed that $32.5 \%$ of pilgrims had viral pathogens: IV in $9.8 \%$, parainfluenza virus in $7.4 \%$, rhinovirus in $5.9 \%$, adenovirus in $5.4 \%$, enterovirus in $2 \%$, RSV in $1.6 \%$, and concurrent infection with 2 viruses in $0.4 \%$. Pathogenic microorganisms were identified from throat swabs in $29.1 \%$ of cases; bacteria represented $18.8 \%$ and viruses $11.1 \%$; isolated agents included streptococci in $11.5 \%$ of cases, meningococci in $7.3 \%$, RSV in $3.1 \%$, IAV $\mathrm{H} 1 \mathrm{~N} 1$ in $3.1 \%$, IBV Sichuan in $2.1 \%$, IAV $\mathrm{H}_{3} \mathrm{~N}_{2}$ in $1.7 \%$, and IBV Hong Kong in 1.1\% (25).

Pneumonia was confirmed in $53.9 \%$ of pilgrims, $94 \%$ of whom were aged > 50 years, with Candida albicans
Figure 2 Flow chart of the search, inclusion and exclusion process

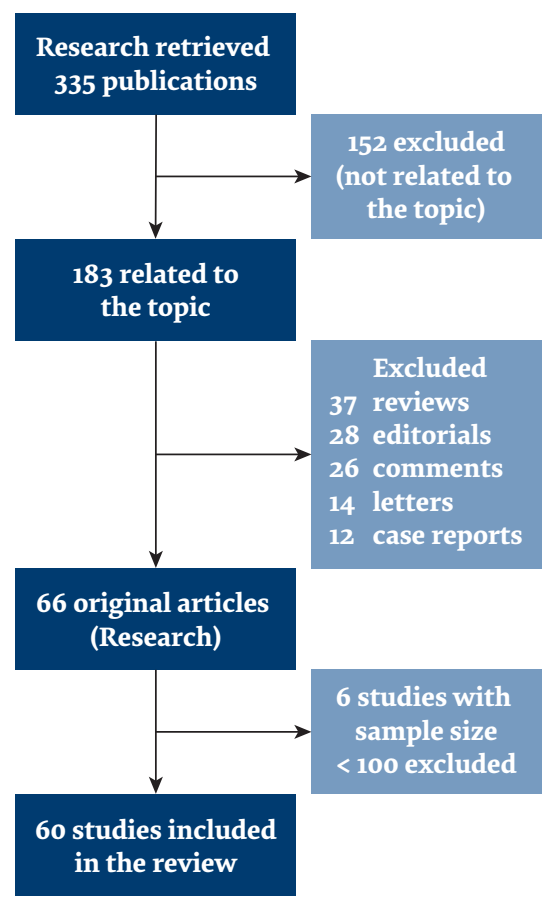

being the most frequent pathogen $(28.7 \%)$, followed by Pseudomonas aeruginosa (21.8\%), Legionella pneumophila $(14.9 \%)$ and Klebsiella pneumoniae (9.2\%) (26). Pneumonia is one of the leading causes of hospitalization of pilgrims in Mecca, especially among elderly people, accounting for $19.7 \%, 22.0 \%$ and $27.2 \%$ of all intensive care unit (ICU) admissions during the Hajj of 2003, 2004 and 2012 respectively (27-29). Pneumonia was also the leading cause of severe sepsis and septic shock among pilgrims admitted to the ICU, and Gram-negative organisms were the most frequently isolated pathogens in this subset of patients (30). About $69 \%$ of the patients received symptomatic treatment and oral antibiotics, and $27.5 \%$ required intravenous antibiotics (31).

In contrast, the prevalence of MRSA among the Hajj pilgrims was low $(1.46 \%)$ in comparison with most community-based studies (32).

The annual risk of tuberculosis (TB) is 3 times higher in Mecca than the national average in Saudi Arabia (12). This situation is not surprising, because $>50 \%$ of pilgrims come from TB-endemic countries. Wilder Smith et al. showed that the TB infection rate was 10\% among Hajj pilgrims, which is higher than the reported incidence of $1.8 \%$ in general travellers to TB-endemic areas (12). TB during the Hajj has the potential to be a source of TB upon return of pilgrims to their home countries.

Some preventive measures are associated with reduced risk of respiratory illness, such as practicing social distancing, hand hygiene, contact avoidance, and washing the throat and mouth with salt water $(30,33)$. However, the high prevalence of respiratory symptoms among Hajj pilgrims indicates that more preventive 
measures are needed (34). The Saudi Ministry of Health recommends the use of facemasks to decrease the risk of respiratory infections. Studies show an increased rate of infections associated with intermittent or non-use of facemasks, compared to using facemasks all the time (13, 17, 35). The Ministry also recommends administration of the seasonal influenza vaccine. Unvaccinated pilgrims contracted IV significantly more frequently than did vaccinated pilgrims (16.5\% vs 9.2\%) (23).

\section{Diarrhoeal diseases}

Cholera and traveller's diarrhoea are common during the Hajj (36). Although few studies have documented the incidence and etiology of cholera during the Hajj, the last case reported was in 1989. Since then, no outbreak has been reported despite the fact that outbreaks occurred in countries from where pilgrims came.

Despite the fact that conditions during the Hajj are theoretically predisposing to hepatitis A, no study has quantified the burden of the disease during the Hajj (37).

A study by Aljasser et al. (35) reported that 9.3\% of pilgrims experienced diarrhoeal symptoms during the Hajj period. In contrast, a study conducted among French pilgrims, reported that only $4.5 \%$ suffered from diarrhoea and $2.4 \%$ from vomiting (38). Gautret et al. (39) evaluated the French pilgrims' potential risk for diseases associated with raw camel milk; only $8.2 \%$ of pilgrims had drunk camel milk before. Although $13.9 \%$ of these pilgrims knew that drinking raw camel milk could cause diseases, $40.6 \%$ would drink it if it were given during the Hajj. The study recommends that Hajj pilgrims be cautious about consuming unpasteurized dairy products. Saeed et al. (40) investigated the occurrence of diarrhoea among Afghani pilgrims before, during and after the Hajj and found that it remained constant over time.

\section{Emerging infectious diseases}

Emerging infectious diseases are of special concern in Hajj health care. Alkhumra virus infection is one of the many examples of these new threatening infections (41). Alkhumra virus infection, which is a haemorrhagic fever, was found in Saudi Arabia for the first time in 1995. During the Hajj of 2001-2003, 37 cases were identified, with a fatality rate of $25 \%$. The disease appeared to be transmitted from goats or sheep to humans via mosquito bites, or by any direct contact with these animals (41). Therefore, to reduce the risk of infection, restrictions are needed for the entry of goats and sheep to the holy sites.

In 2009, IAV $\mathrm{HiN} 1$ presented a potentially massive threat to Hajj pilgrims, mainly because Saudi Arabia ranked fourth in probable swine flu cases and deaths in the Eastern Mediterranean Region $(42,43)$. Moreover, a large number of pilgrims were from resource-limited countries; therefore, only a minority of pilgrims was likely to have had access to IAV HiN1 vaccine before they travelled to Saudi Arabia for the Hajj (42). In France, some members of the Muslim community do not receive nationally provided preventive health care, due to inequities (44). Furthermore, the acceptance rate for vaccination is low even with when resources are available (45). Among pilgrims performing the Hajj, reluctance to receive prophylaxis or preventive care can increase the risk of transmitting and acquiring infectious diseases. Somewhat surprisingly, even when administered, seasonal influenza vaccine is reported to be insufficiently protective against influenza among Hajj pilgrims (46), and another study to verify this evidence is recommended. Healthcare workers (HCWs) during the Hajj season of 2009 reported a low rate of vaccination against pandemic IAV $\mathrm{H1N} 1$ (22\%) (43). In contrast, they reported high rates of maintaining hand hygiene (98\%), cough etiquette (89\%) and wearing a facemask (90\%). None of the HCWs had influenza A HiN1. Another study conducted in Hajj 2009 showed that among 3133 pilgrims, 3 cases of influenza $\mathrm{A}(\mathrm{H1N} 1)$ were identified (47). Among Iranian pilgrims, 5 cases of influenza A $(\mathrm{H1N} 1)$ were identified $(48,49)$. The low prevalence of pandemic influenza A ( $\mathrm{H} 1 \mathrm{~N} 1)$ during Hajj pilgrimages may be the result of procedures implemented by Saudi authorities, including rapid implementation of a pandemic $\mathrm{H}_{1} \mathrm{~N} 1$ vaccination programme that targeted all medical personnel and vulnerable populations, including young children, older adults and pregnant women (50). Other measures included thermal screening equipment to detect febrile passengers arriving at Saudi Arabian airport terminals (51) and a 24-hour specialized ENT clinic to address emergency cases and possible pandemic $\mathrm{H} 1 \mathrm{~N} 1$ cases, and to reduce pressure on the emergency department (50).

In the 2013 Hajj season, a cohort of 5235 pilgrims was screened for nasal carriage of MERS-related coronavirus (MERS-CoV). No case of MERS-CoV nasal carriage was detected by 2 reverse transcription polymerase chain reactions (52). In response to the MERS-CoV situation, the Saudi Ministry of Health and the US Centers for Disease Control and Prevention (CDC) recommended that people with chronic diseases (such as heart, respiratory and kidney disease, and diabetes), elderly people, and pilgrims with immune deficiency, malignant diseases, and terminal illnesses, in addition to children and pregnant women, postpone their performance of the 2013 Hajj for their own safety (52).

Reporting outbreaks of infectious disease allows Saudi Arabia to take the necessary measures to prevent spread of such disease among pilgrims during the Hajj. Laxminarayan et al. (53) have shown that incentives, if not restricted to financial assistance, can modify reporting decisions, particularly when the burden of disease is low. New policies have been implemented in response to emerging infectious diseases, such as administering polio vaccine to pilgrims on arrival in Saudi Arabia, reducing Hajj quotas for foreign and domestic pilgrims in 2013, and strengthening the surveillance system for infectious diseases with involvement of international agencies (3).

\section{Noncommunicable diseases}

\section{Pre-existing chronic illness}

Pilgrims with pre-existing cardiac diseases are at high risk of physical stress that leads to ischaemia. Cardiovas- 
cular diseases are the most common cause of death during the Hajj, accounting for $66 \%$ of all deaths according to Pane et al. (54). Furthermore, that study also reported that cardiovascular disease accounted for $63.6 \%$ of ICU admissions, and was the second most common cause for admission to hospital (12.3\%) $(27,28)$. These high rates may have been due to the high number of elderly people with chronic diseases among the pilgrims (28). Another study conducted in the ICU reported that $37.3 \%$ of cases admitted to ICU were pilgrims who were critically ill due to cardiovascular diseases $(23.6 \%$ with myocardial infarction) (55). Therefore, pre-Hajj functional assessment should be carried out to identify patients at a high risk of mortality from cardiovascular diseases (56). A cohort study conducted among Iranian pilgrims in the $2007 \mathrm{Hajj}$ showed that 17 first-ever strokes occurred in the pilgrims (5 men and 12 women) (57).

Among all hospital admissions, nephrological diseases accounted for $2 \%$ (58). Such conditions have good outcomes and do not need special care. This aspect of inpatient care does not seem to need special interventions or recommendations.

\section{Trauma}

The mass movement of millions of pilgrims from one ritual place to another, in a short time and in a small area, significantly increases the risk of trauma. $\mathrm{Nu}$ merous accidents and injuries face Hajj pilgrims, such as falling, sliding, stampede, and traffic accidents (59). Most of the traumas usually occur during the rituals of Tawaf, Saee and Ramy al-jamarat (59). Trauma accounted for 9.4\% (27) of hospital admissions and 6.4\% (28) of ICU admissions. The incidence of head and eye injuries during Ramy al-jamarat in 2005 was significantly lower than in 2004 (60). This improvement may have been due to the changed structure of Ramy al-jamarat in Hajj 2005. In contrast, the rate of all-cause fractures in 2005 was higher than in 2004 among Iranian pilgrims, perhaps because of increased overcrowding (60). Fire may also be considered among the causes of traumatic injuries. The incidence of burns was about 40/10 000 (59). However, cooking food is not allowed at Mina, and smoking is forbidden during the Hajj by Islamic teaching, thus reducing the risk of fires.

\section{Surgery}

Surgical problems, either acute surgical emergency or precipitation of chronic disease, are not uncommon during the Hajj season. In a study conducted in 2003 and 2004, 177 patients were admitted to a surgical ward (61). Most of the patients were male (78.5\%), and the mean age of patients was 52.7 years; however, $41 \%$ of patients were aged $>60$ years $(61)$. The most common causes of admission were acute appendicitis and diabetic foot, followed by traumatic injuries and obstructed hernias (61). Nearly half of the patients (49.1\%) received surgical treatment, while $39 \%$ were managed conservatively, and $11.3 \%$ of patients left the hospital against medical advice (61).

\section{Heat injury}

Heat stress is one of the main complaints among Hajj pilgrims (62). The high air temperatures, sun exposure, and heat dissipated from the large number of people and vehicles all contribute to the problem of heat stress. The highest incidence of heat fatalities occurred when the maximum air temperature reached $48.7^{\circ} \mathrm{C}$. In recent years, the incidence of heat stroke and exhaustion has been low, which is probably due to improvement in climatic conditions since the Hajj seasons have been occurring in the winter. It is important to minimize heat exposure by developing awareness of the signs and symptoms of heat stress, avoiding excessive sun exposure by using umbrellas and seeking shade, wearing sun block creams, and drinking adequate fluid. There are some preventative measures already established by the Saudi authorities, such as making drinking water available for all pilgrims, and providing water mist sprayers that operate regularly in the places were the Hajj rituals are performed (62).

\section{Hajj health services}

The Saudi Ministry of Health provides free health services for all pilgrims during the Hajj period. However, few studies have investigated these services, and they are mostly limited to hospital settings.

A study conducted to evaluate the effect of infection control practice in all the hospitals in Mecca during the Hajj from 2003 to 2006, showed some deficiencies, including lack of infection control units, infection control committees, infection control educational activities and surveillance systems, and a shortage of staff (63). However, these deficiencies were improved in the subsequent audits. Another study in 2003 assessed knowledge, attitude and practice, related to infection control among HCWs in hospitals and primary care centres during the Hajj (64). There was noticeable deficiency in knowledge concerning important infection control measures. A different study addressing the knowledge of HCWs about preventive measures for communicable diseases among pilgrims in 2011 showed that most of the participants had good knowledge about meningococcal meningitis, except for preventive measures applied to infants and children (65). Madani et al. found that the meningococcal and hepatitis B vaccination coverage level among HCWs in the Hajj was below the accepted standard, and that the influenza vaccination level was remarkably low (66). The authors recommended developing strategies to improve vaccination coverage among HCWs, and that these strategies should be practiced by all healthcare facilities in Saudi Arabia.

Patient satisfaction is an essential factor in evaluating the quality of healthcare services. Only 1 study assessed pilgrims' satisfaction with the ambulatory health services at the Hajj. An overall level of acceptable satisfaction was reported by $82 \%$ of respondents; the score was 61.5 of 75 points (67). The lowest level of satisfaction was reported for physicians' services, which were identified as needing special attention to improve pilgrims' satisfaction. More studies are needed to evaluate the Hajj health services, and make recommendations for their improvement. 


\section{Future of health care at the Hajj}

The Saudi Ministry of Health takes the Hajj season seriously. It starts to plan for the next season immediately after finishing the current season by gathering feedback from local and international health agencies (3), and publishes annually public health recommendations and regulations to prevent and control health threats during the Hajj. The Saudi authorities do not currently directly supervise implementation of the strict Hajj health regulations outside its borders. Instead they depend on pilgrims' host countries for that task. For example, each pilgrim should provide a valid vaccination certificate to obtain a Hajj visa. However, it is not known who could ensure that the certificate is valid. Two Saudi studies (68, $69), 6$ years apart, showed that $44-46.5 \%$ of pilgrims did not take their required meningitis vaccine during the recommended period (10 days- 3 years before arrival on the Hajj), and therefore may have become a potential source of infectious disease. To overcome such a problem, the Saudi authorities could help to ensure Hajj health regulations are implemented by strengthening the public health systems in pilgrims' host countries. This could come in the form of outreach training programmes for public health professionals, healthcare providers, and health system research projects as part of what is known as global health diplomacy.

The Hajj is a unique opportunity to apply the concept of global health diplomacy, and the benefits from international collaboration and cooperation. Global health diplomacy is crucial to managing health hazards in international health settings such as the Hajj, and decreases the risk of pandemics by planning cross-border vaccination programmes, developing visa quotas, providing international disease outbreak surveillance, and arranging rapid repatriation. One example of global cooperation is that between the Saudi Ministry of Health, World Health Organization, and the US CDC, in response to the threat of pandemic influenza $\mathrm{A} \mathrm{H} 1 \mathrm{~N} 1$, which overlapped with the Hajj in 2009. The efforts by these organizations to decrease pandemic influenza $\mathrm{A} \mathrm{H1N} 1$ resulted in the creation of one of the largest, real-time mobile database systems in the world, which was designed to detect disease in real time at any mass gathering. In 2012 the conventional paper-based information system was converted into a digital system to facilitate rapid data sharing with international agencies (3).
Health authorities in the countries of origin must provide information to their Hajj pilgrims on the potential health hazards and preventive measures for each. For example, pilgrims should be provided with information on infectious disease symptoms, modes of transmission, complications and preventive measures. Moreover, Hajj pilgrims should be informed about the items and foods that are not allowed in Saudi Arabia, such as the ban on fresh food, which is in place to reduce the spread of food-borne infections during the Hajj. In addition, they should prepare their pilgrims to take precaution against influenza, by taking the vaccine, as the Hajj season is moving towards winter. Several initiatives, including the establishment of the Global Center for Mass Gathering Medicine (3), are in place to learn from and share the Saudi experience in managing the mass-gathering-related public health aspects of the Hajj, since much robust expertise has been gained. Moreover, there is an initiative to establish a University of Hajj, with an international research centre that provides education and training to improve Hajj services. This proposed university could also facilitate sharing Saudi experience with health systems around the world, thus strengthening the Hajj health system (70).

The limitations of the present study were restriction to English-language articles, the dependence on 3 databases only, and not searching the grey literature (e.g., masters and doctoral theses).

\section{Conclusion}

Among the lessons learned from this review are, the need for large-scale scientific studies to quantify the burden of infectious diseases such as hepatitis A, B and C. Despite the absence of infectious disease outbreaks during Hajj in recent years, emerging infectious diseases represent a threat in the light of the expected increasing number of pilgrims after the completion of construction in the Grand Mosque and the sacred areas of the Hajj. The vast development in infectious disease surveillance after the development of the web-based healthcare network is a welcome achievement of the Saudi Ministry of Health. The optimal utilization of the collected data is yet to be achieved. The existing international collaboration needs to be strengthened and expanded.

Funding: None.

Competing interests: None declared. 


\section{Problèmes de santé pendant le pèlerinage du Hadj : examen de la littérature \\ Résumé}

Le pèlerinage du Hadj à La Mecque, en Arabie saoudite, l'un des plus grands rassemblements de masse annuels au monde, a un fort impact sur la santé publique internationale. Le présent article présente une vue d'ensemble à partir d'une recherche systématique dans la littérature publiée sur les risques sanitaires et les services de santé durant le Hadj pour la période 2005-2014, dans le but de fournir des recommandations de politique sanitaire en vue de prévenir les risques sanitaires. Sur les 335 études identifiées initialement, 60 répondaient aux critères d'inclusion fixés pour l'examen. Les études recensées étaient diverses sur le plan de la méthodologie et de l'orientation. Les résultats sont classés en trois grandes catégories : maladies transmissibles, maladies non transmissibles et services de santé. Bien que des améliorations aient été observées au fil des années, il existe toujours de nouveaux défis de santé publique à chaque saison du Hadj. Il est nécessaire d'améliorer la gestion sanitaire du Hadj, en particulier en renforçant la collaboration internationale.

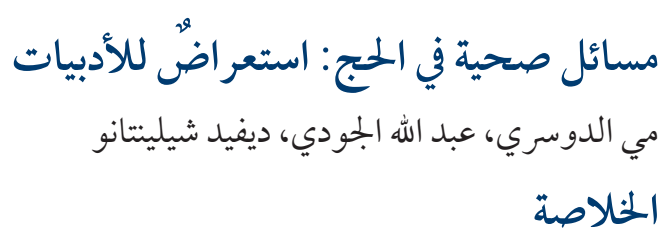

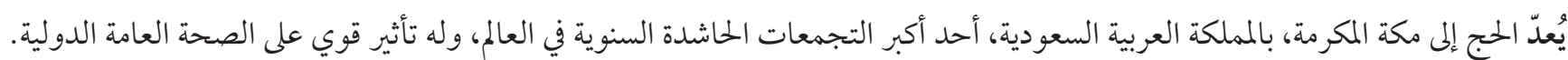

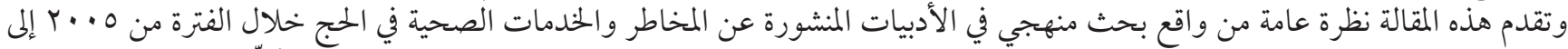

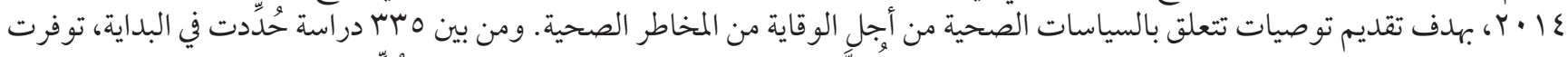

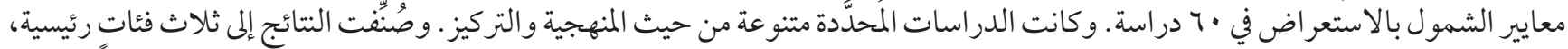

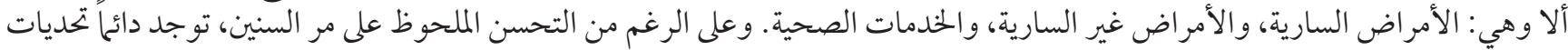

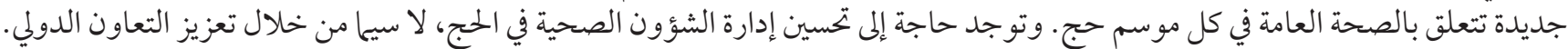

\section{References}

1. Fouda A. A study to estimate the number of worshippers at the Grand Mosque. Government report. Umm Al-Qura Univ, Mecca, Kingdom of Saudi Arabia; 1998.

2. Statistical Year Book 1437H. Riyadh; Saudi Arabia, Ministry of Health; 2016.

3. Memish ZA, Zumla A, Alhakeem RF, Assiri A, Turkestani A, Al Harby KD, et al. Hajj: infectious disease surveillance and control. Lancet. 2014 Jun 14;383(9934):2073-82. http://dx.doi.org/10.1016/So140-6736(14)60381-0 PMID:24857703

4. Ahmed Q, Arabi Y, Memish Z. Health risk at the Hajj. Lancet. 2006 Mar 25;367(9515):1008-15. http://dx.doi.org/10.1016/So1406736(06)68429-8 PMID:16564364

5. Memish ZA, Al Hakeem R, Al Neel O, Danis K, Jasir A, Eibach D. Laboratory-confirmed invasive meningococcal disease: effect of the Hajj vaccination policy, Saudi Arabia, 1995 to 2011. Euro Surveill. 2013 Sep 12;18(37). PMID:24079399

6. Nicolas P, Ait M'barek N, Al-Awaidy S, Al Busaidy S, Sulaiman N, Issa M et al. Pharyngeal carriage of serogroup W135 Neisseria meningitidis in Hajjees and their family contacts in Morocco, Oman and Sudan. APMIS. 2005 Mar;113(3):182-6. http:dx/doi. org/10.1111/j.1600-0463.2005.apm1130305.x PMID:15799761

7. Karsany MS, Elshayeb AA, Saeed ES, Elaagib R, Ibrahim SA, Elsamani E et al. Patterns of meningococcal infection in Sudan with emergence of Neisseria meningitidis serogroup W135. East Mediterr Health J. 2013 Oct;19(10):843-6. PMID:24313147

8. Dull PM, Abdelwahab J, Sacchi CT, Becker M, Noble CA, Barnett GA et al. Neisseria meningitidis serogroup W-135 carriage among US travelers to the 2001 Hajj. J Infect Dis. 2005 Jan 1;191(1):33-9. http://dx.doi.org/10.1086/425927 PMID:15593000

9. Lemos APS, Harrison LH, Lenser M, Sacchi CT. Phenotypic and molecular characterization of invasive serogroup W135 Neisseria meningitidis strains from 1990 to 2005 in Brazil. J Infect. 2010 Mar;60(3):209-17. http://dx.doi.org/10.1016/j.jinf.2009.11.014 PMID:20056121

10. Ceyhan M, Celik M, Demir ET, Gurbuz V, Aycan AE, Unal S. Acquisition of meningococcal serogroup W-135 carriage in Turkish Hajj pilgrims who had received the quadrivalent meningococcal polysaccharide vaccine. Clin Vaccine Immunol 2013 Jan;20(1):66-8. http://dx.doi.org/10.1128/CVI.00314-12 PMID:23136117

11. Alborzi A, Oskoee S, Pourabbas B, Alborzi S, Astaneh B, Gooya MM et al. Meningococcal carrier rate before and after Hajj pilgrimage: effect of single dose ciprofloxacin on carriage. East Mediterr Health J. 2008 Mar-Apr;14(2):277-82. PMID:18561718

12. Wilder-Smith A, Foo W, Earnest A, Paton NI. High risk of Mycobacterium tuberculosis infection during the Hajj pilgrimage. Trop Med Int Health. 2005 Apr;10(4):336-9. http://dx.doi.org/10.1111/j.1365-3156.2005.01395.x PMID:15807797

13. Al-Asmary S, Al-Shehri AS, Abou-Zeid A, Abdel-Fattah M, Hifnawy T, El-Said T et al. Acute respiratory tract infections among Hajj medical mission personnel, Saudi Arabia. Int J Infect Dis. 2007 May;11(3):268-72. http://dx.doi.org/10.1016/j.ijid.2006.04.008 


\section{PMID:16905350}

14. Alzahrania A, Choudhrya AJ, Al Mazroa MA, Turkistani AH, Nouman GS, Memish ZA. Pattern of diseases among visitors to Mina health centers during the Hajj season, (2008 G). J Infect Public Health. 2012 Mar;5(1):22-34. http://dx.doi.org/10.1016/j. jiph.2011.10.003 PMID:22341840

15. Shakir HAS, Gazzaz ZJ, Dhaffar KO, Shahbaz J. Outpatient services during (1423h) Hajj Season. Sultan Qaboos Univ Med J. 2006 Jun;6(1):47-50. PMID:21748127

16. Alherabi AZ. Road map of an ear, nose, and throat clinic during the 2008 Hajj in Mecca, Saudi Arabia. Saudi Med J. 2009 Dec;30(12):1584-9 PMID:19936425

17. Choudhry AJ, Al-Mudaimegh KS, Turkistani AM, Al-Hamdan NA. Hajj-associated acute respiratory infection among hajjis from Riyadh. East Mediterr Health J. 2006 May-Jul;12(3-4):300-9. PMID:17037698

18. Gautret P, Yong W, Soula G, Gaudart J, Delmont J, Dia A. Incidence of Hajj-associated febrile cough episodes among French pilgrims: a prospective cohort study on the influence of statin use and risk factors. Clin Microbiol Infect. 2009 Apr;15(4):335-40. http://dx.doi.org/10.1111/j.1469-0691.2009.02816.x PMID:19416305

19. Deris ZZ, Hasan H, Sulaiman SA, Wahab MS, Naing NN, Othman NH. Preference of treatment facilities among Malaysian Hajj pilgrims for acute respiratory tract symptoms. Saudi Med J. 2009 Aug;30(8):1103-4. PMID:19668898

20. Deris ZZ, Hasan H, Ab Wahab MS, Sulaiman SA, Naing NN, Othman NH. The association between pre-morbid conditions and respiratory tract manifestations amongst Malaysian Hajj pilgrims. Trop Biomed. 2010 Aug;27(2):294-300. PMID:20962728

21. Rashid H, Shafi S, Booy R, El Bashir H, Ali K, Zambon M et al. Influenza and respiratory syncytial virus infections in British Hajj pilgrims. Emerg Health Threats J. 2008;1:e2. http://dx.doi.org/10.3134/ehtj.08.002 PMID:22460211

22. Rashid H, Shafi S, Haworth E, , El Bashir H, Memish ZA, Sudhanva M et al. Viral respiratory infections at the Hajj: comparison between UK and Saudi pilgrims. Clin Microbiol Infect. 2008 Jun;14(6):569-74. http://dx.doi.org/10.1111/j.1469-0691.2008.01987.x PMID:18373688

23. Alborzi A, Aelami MH, Ziyaeyan M, Jamalidoust M, Moeini M, Pourabbas B et al. Viral etiology of acute respiratory infections among Iranian Hajj pilgrims, 2006. J Travel Med. 2009 Jul-Aug;16(4):239-42. http://dx.doi.org/10.1111/j.1708-8305.2009.00301.x PMID:19674262

24. Benkouiten S, Charrel R, Belhouchat K, Drali T, Salez N, Nougairede A et al. Circulation of respiratory viruses among pilgrims during the 2012 Hajj pilgrimage. Clin Infect Dis. 2013 Oct;57(7):992-100o. http://dx.doi.org/10.1093/cid/cit446 PMID:23839997

25. AbdulRahman NK, Chaudhry AJ, Al Mazroa M. Etiology of upper respiratory tract infection among international pilgrims arriving for Hajj 2010 G. Saudi Epidemiol Bull. 2011;19(2):14-15.

26. Asghar AH, Ashshi AM, Azhar EI, Bukhari SZ, Zafar TA, Momenah AM. Profile of bacterial pneumonia during Hajj. Indian J Med Res. 2011 May;133:510-3. PMID:21623036

27. Madani TA, Ghabrah TM, Al-Hedaithy MA, Alhazmi MA, Alazraqi TA, Albarrak AM et al. Causes of hospitalization of pilgrims in the Hajj season of the Islamic year 1423 (2003). Ann Saudi Med. 2006 Sep-Oct;26(5):346-51. Ann Saudi Med. 2006; 26(5):346-351. http://dx.doi.org/10.5144/0256-4947.2006.346 PMID:17019102

28. Madani TA, Ghabrah TM, Albarrak AM, Alhazmi MA, Alazraqi TA, Althaqafi AO et al. Causes of admission to intensive care units in the Hajj period of the Islamic year 1424 (2004). Ann Saudi Med. 2007 Mar-Apr;27(2):101-5. http://dx.doi.org/10.5144/02564947.2007.101 PMID:17356316

29. Mandourah Y, Al-Radi A, Ocheltree AH, Ocheltree SR, Fowler RA. Clinical and temporal patterns of severe pneumonia causing critical illness during Hajj. BMC Infect Dis. 2012 May 16;12:117. http://dx.doi.org/10.1186/1471-2334-12-117 PMID:22591189

30. Baharoon S, Al-Jahdali H, Al Hashmi J, Memish ZA, Ahmed QA. Severe sepsis and septic shock at the Hajj: etiologies and outcomes. Travel Med Infect Dis. 2009 Jul;7(4):247-52. http://dx.doi.org/10.1016/j.tmaid.2008.09.002 PMID:19717109

31. Emamian MH, Hassani AM, Fateh M. Respiratory tract infections and its preventive measures among Hajj pilgrims, 2010: a nested case control study. Int J Prev Med. 2013 Sep;4(9):1030-5. PMID:24130944

32. Memish ZA, Balkhy HH, Almuneef MA, Al-Haj-Hussein BT, Bukhari AI, Osoba AO. Carriage of Staphylococcus aureus among Hajj pilgrims. Saudi Med J. 2006 Sep;27(9):1367-72. PMID:16951775

33. Balaban V, Stauffer WM, Hammad A, Afgarshe M, Abd-Alla M, Ahmed Q et al. Protective practices and respiratory illness among US travelers to the 2009 Hajj. J Travel Med. 2012 May-Jun;19(3):163-8. http://dx.doi.org/10.1111/j.1708-8305.2012.00602.x PMID:22530823

34. Deris ZZ, Hasan H, Sulaiman SA, Wahab MS, Naing NN, Othman NH. The prevalence of acute respiratory symptoms and role of protective measures among Malaysian hajj pilgrims. J Travel Med. 2010 Mar-Apr;17(2):82-8. http://dx.doi.org/10.1111/j.17088305.2009.00384.x PMID:20412173

35. Al-Jasser FS, Kabbash IA, AlMazroa MA, Memish ZA. Patterns of diseases and preventive measures among domestic hajjis from central, Saudi Arabia. Saudi Med J. 2012 Aug;33(8):879-86. PMID: 22886122

36. Gautret P, Benkouiten S, Sridhar S, Al-Tawfiq JA, Memish ZA. Diarrhea at the Hajj and Umrah. Travel Med Infect Dis. 2015 MarApr;13(2):159-66. http://dx.doi.org/10.1016/j.tmaid.2015.02.005 PMID:25765485

37. Rafiq SM, Rashid H, Haworth E, Booy R. Hazards of hepatitis at the Hajj. Travel Med Infect Dis. 2009 Jul;7(4):239-46. http://dx. doi.org/10.1016/j.tmaid.2008.09.008 PMID:19717108 
38. Gautret P, Soula G, Delmont J, Parola P, Brouqui P. Common health hazards in French pilgrims during the Hajj of 2007: a prospective cohort study. J Travel Med. 2009 Nov-Dec;16(6):377-81. http://dx.doi.org/10.1111/j.1708-8305.2009.00358.x PMID:19930376

39. Gautret P, Benkouiten S, Gaillard C, Parola P, Brouqui P. Camel milk-associated infection risk perception and knowledge in French Hajj pilgrims. Vector Borne Zoonotic Dis. 2013 Jun;13(6):425-7. http://dx.doi.org/10.1089/vbz.2012.1010 PMID:23725087

40. Saeed KMI, Mofleh J, Rasooly MH, Aman MI. Occurrence of acute respiratory infection, diarrhea and jaundice among Afghan pilgrims, 2010. J Epidemiol Glob Health. 2012 Dec;2(4):215-20. http://dx.doi.org/10.1016/j.jegh.2012.11.003 PMID:23856503

41. Madani TA. Alkhumra virus infection, a new viral hemorrhagic fever in Saudi Arabia. J Infect. 2005 Aug;51(2):91-7. PMID:16038757

42. Khan K, Memish ZA, Chabbra A, Liauw J, Hu W, Janes DA et al. Global public health implications of a mass gathering in Mecca, Saudi Arabia during the midst of an influenza pandemic. J Travel Med. 2010 Mar-Apr;17(2):75-81. http://dx.doi.org/10.1111/j.17088305.2010.00397.x PMID:20412172

43. Memish ZA, Assiri AM, Alshehri M, Hussain R, Alomar I.. The prevalence of respiratory viruses among healthcare workers serving pilgrims in Mecca during the 2009 influenza A (H1N1) pandemic. Travel Med Infect Dis. 2012 Jan;10(1):18-24. http://dx.doi. org/10.1016/j.tmaid.2011.11.002 PMID:22197024

44. Gautret P, Yong W, Soula G, Parola P, Brouqui P, DelVecchio Good MJ. Determinants of tetanus, diphtheria and poliomyelitis vaccinations among Hajj pilgrims, Marseille, France. Eur J Public Health. 2010 Aug;20(4):438-42. http://dx.doi.org/10.1093/eurpub/ckp196 PMID:19959614

45. Keles H, Sonder GJB, van den Hoek A. Predictors for the uptake of recommended vaccinations in Mecca travelers who visited the Public Health Service Amsterdam for mandatory meningitis vaccination. J Travel Med. 2011 May-Jun;18(3):198-202. http:// dx.doi.org/10.1111/j.1708-8305.2011.00515.x PMID:21539660

46. Rashid H, Shafi S, Haworth E, Memish ZA, El Bashir H, Ali KA et al. Influenza vaccine in Hajj pilgrims: policy issues from field studies. Vaccine. 2008 Sep 2;26(37):4809-12. http://dx.doi.org/10.1016/j.vaccine.2008.07.001 PMID:18640171

47. Memish ZA, Assiri AM, Hussain R, Alomar I, Stephens G. Detection of respiratory viruses among pilgrims in Saudi Arabia during the time of a declared Influenza A(H1N1) Pandemic. J Travel Med. 2012 Jan-Feb;19(1):15-21. http://dx.doi.org/10.1111/j.17088305.2011.00575.x PMID:22221807

48. Ziyaeyan M, Alborzi A, Jamalidoust M, Moeini M, Pouladfar GR, Pourabbas B et al. Pandemic 2009 influenza A (H1N1) infection among 2009 Hajj pilgrims from Southern Iran: a real-time RT-PCR-based study. Influenza Other Respir Viruses. 2012 Nov;6(6):e80-4. http://dx.doi.org/10.1111/j.1750-2659.2012.00381.x PMID: 22583661

49. Moattari A, Emami A, Moghadami M, Honarvar B. Influenza viral infections among the Iranian Hajj pilgrims returning to Shiraz, Fars province, Iran. Influenza Other Respir Viruses. 2012 Nov;6(6):e77-9. http://dx.doi.org/10.1111/j.1750-2659.2012.00380.x PMID:22606996

50. Alherabi AZ. Impact of pHiNi influenza A infections on the otolaryngology, head and neck clinic during Hajj, 2009. Saudi Med J. 2011 Sep;32(9):933-8 PMID:21894357

51. Ebrahim SH, Memish ZA, Uyeki TM, Khoja TA, Marano N, McNabb SJ. Pandemic H1N1 and the 2009 Hajj. Science. 2009 Nov 13;326(5955):938-40. http://dx.doi.org/10.1126/science.1183210 PMID:19933105

52. Memish ZA, Assiri A, Almasri M, Alhakeem RF, Turkestani A, Al Rabeeah AA et al. Prevalence of MERS-CoV nasal carriage and compliance with the Saudi health recommendations among pilgrims attending the 2013 Hajj. J Infect Dis. 2014 Oct 1;210(7):106772. http://dx.doi.org/10.1093/infdis/jiu150 PMID:24620019

53. Laxminarayan R, Reif J, Malani A. Incentives for reporting disease outbreaks. PLoS One. 2014 Mar 6;9(3):e90290. http://dx.doi. org/10.1371/journal.pone.0090290 PMID:24603414

54. Pane M, Imari S, Alwi Q, Nyoman Kandun I, Cook AR, Samaan G. Causes of mortality for Indonesian Hajj pilgrims: comparison between routine death certificate and verbal autopsy findings. PLoS One. 2013 Aug 21;8(8):e73243. http://dx.doi.org/10.1371/journal.pone.0073243 PMID:23991182

55. Mandourah Y, Ocheltree A, Al Radi A, Fowler R. The epidemiology of Hajj-related critical illness: lessons for deployment of temporary critical care services. Crit Care Med. 2012 Mar;40(3):829-34. http://dx.doi.org/10.1097/CCM.obo13e318236f49b PMID:22080635

56. Khan NA, Ishag AM, Ahmad MS, El-Sayed FM, Bachal ZA, Abbas TG. Pattern of medical diseases and determinants of prognosis of hospitalization during 2005 Muslim pilgrimage (Hajj) in a tertiary care hospital. Saudi Med J. 2006 Sep;27(9):1373-80. PMID:16951776

57. Azarpazhooh MR, Shahripour RB, Kapral MK, Mokhber N, Shoeibi A, Farzadfard MT et al. Incidence of first ever stroke during Hajj Ceremony. BMC Neurol. 2013 Dec 5;13:193. http://dx.doi.org/o.1186/1471-2377-13-193 PMID:24308305

58. Hollisaz MT, Pourheidari G, Saghafinia M, Khanipour-Roshan S, Assari S. Hospital admission due to nephrological conditions during Hajj. Iran J Kidney Dis. 2010 Jan;4(1):71-3. PMID:20081308

59. Razavi SM, Ardakani HZ, Rajai S, Hollisaz M, Sadeghipoor H, Farshad A et al. Trends in prevalent injuries among Iranian pilgrims in Hajj. Iran J Public Health. 2011;40(2):110-5. PMID:23113080

6o. Meysamie A, Ardakani HZ, Razavi SM, Doroodi T. Comparison of mortality and morbidity rates among Iranian pilgrims in Hajj 2004 and 2005. Saudi Med J. 2006 Jul;27(7):1049-53. PMID:16830029 
61. Al-Salamah SM. General surgical problems encountered in the Hajj pilgrims. Saudi Med J. 2005 Jul;26(7):1055-7. PMID:16047051

62. Noweir MH, Bafail AO, Jomoah IM. Study of heat exposure during Hajj (pilgrimage). Environ Monit Assess. 2008 Dec;147(13):279-95. http://dx.doi.org/10.1007/s10661-007-0120-6. PMID:18266067

63. Madani TA, Albarrak AM, Alhazmi MA, Alazraqi TA, Althaqafi AO, Ishaq AH. Steady improvement of infection control services in six community hospitals in Mecca following annual audits during Hajj for four consecutive years. BMC Infect Dis. 2006 Aug 25;6:135. PMID:16934152

64. Ghabrah TM, Madani TA, Albarrak AM, Alhazmi MA, Alazraqi TA, Alhudaithi MA et al. Assessment of infection control knowledge, attitude and practice among healthcare workers during the Hajj period of the Islamic year 1423 (2003). Scand J Infect Dis. 2007;39(11-12):1018-24. PMID:17852933

65. Al-Ghamdi AS, Kabbash IA. Awareness of healthcare workers regarding preventive measures of communicable diseases among Hajj pilgrims at the entry point in Western Saudi Arabia. Saudi Med J. 2011 Nov;32(11):1161-7. PMID:22057605

66. Madani TA, Ghabrah TM. Meningococcal, influenza virus, and hepatitis B virus vaccination coverage level among health care workers in Hajj. BMC Infect Dis. 2007 Jul 18;7:80. PMID:17640374

67. Al-Hoqail IA, Abdalla AM, Saeed AA, Al-Hamdan NA, Bahnassy AA. Pilgrims satisfaction with ambulatory health services in Mecca, 2008. J Family Community Med. 2010 Sep;17(3):135-40. http://dx.doi.org/10.4103/1319-1683.74331. PMID:21359024

68. Al-Maghderi Y, Al-joudi A, Choudhry AJ, Al-Rabeah AM, Ibrahim M, Turkistani AM. Behavioral risk factors for diseases during Hajj, 1422H. Saudi Epidemiol Bull. 2002;9(3):19-20.

69. Al-Faraj N, Choudhry AJ, Al-Hayani O. Behavioural risk factors for diseases during Hajj $1428 \mathrm{H}$. Saudi Epidemiol Bull. 2008;15(4):28-31.

70. Aljoudi AS. A University of the Hajj? Lancet. 2013 Nov 23;382(9906):1689. http://dx.doi.org/10.1016/So140-6736(13)62340-5. PMID:24267989. 